\title{
The Role of Science in the History of Portuguese Anti-Jesuitism
}

\author{
Henrique Leitão \\ CIUнст, Faculdade de Ciências, Universidade de Lisboa \\ leitao.henrique@gmail.com \\ Francisco Malta Romeiras \\ CIU HCT, Faculdade de Ciências, Universidade de Lisboa \\ franciscomesquitella@gmail.com
}

\begin{abstract}
When dealing with the expulsion of the Jesuits from Portugal and with the building of anti-Jesuitism in the eighteenth century, historians usually focus on their alleged involvement in the attempt to murder king Dom José I and on the complex economical questions related with the foundation of the state trade company in Brazil. However, the Pombaline accusation of obscurantism and scientific illiteracy also played a central role in the history of anti-Jesuitism in Portugal, mainly due to its wide acceptance and longevity. This argument was not only directly relevant for the expulsion of the Jesuits in the eighteenth century but it was also a keystone of the anti-Jesuit propaganda that eventually led to the expulsion of the Society of Jesus from Portugal in the twentieth century.
\end{abstract}

\section{Keywords}

anti-Jesuitism - expulsion of the Jesuits - Portuguese Jesuits - Marquis of Pombal obscurantism - anticlericalism - republican revolution - history of science - science education - scientific popularization

Although anti-Jesuitism was born with the very foundation of the Society of Jesus and had a long and convoluted history, it is perhaps safe to say that it 
reached its zenith and maximum strength in eighteenth-century Portugal. ${ }^{1}$ The direct role of Sebastião José de Carvalho e Melo (1699-1782) — the well known Marquis of Pombal -in the expulsion of the Jesuits from the Portuguese empire (1759), his indirect action in the expulsion of the Jesuits from other European countries, and his decisive influence in the suppression of the Society by Pope Clement XIV (1773) are well known and well attested. Pombal set up an anti-Jesuit campaign of unprecedented strength, scope, and virulence. Although the full force of the campaign was felt most of all in Portugal, its effects rapidly spread to all of Europe and even to regions outside Europe. By bringing together old accusations and adding new ones, and most of all by investing immense resources and careful planning in his propagandistic endeavor Pombal became a major contributor to spreading the image of the Jesuits as sinful, decadent, ambitious, deceitful, reactionary, and mediocre. Pombal's violent animosity towards the Jesuits and his campaigning against the Society are well known, but we believe that a more detailed inspection of the arguments used is required since, as it turns out, at least one of the accusations displayed a surprising longevity and ultimately contributed to shaping the image of the Society in the following centuries.

Pombal deployed against the Society of Jesus a sophisticated arsenal that included political, diplomatic, and economic actions. The core of his campaigning, however, was a massive publishing offensive. Under Pombal's orders and supervision, hundreds of printed works of all sorts condemning the Jesuits and their apostolates (pamphlets, reports, books, treatises, theatre plays, etc.) were published and distributed all over Europe. This was a gigantic operation, well planned and sustained throughout roughly two decades, most likely the widest and most ambitious propaganda campaign in Europe up to the eighteenth century. ${ }^{2}$

1 Anti-Jesuitism has been an important subject of study in the past. Recently, it was suggested that anti-Jesuitism shares some features typical of a "conspiracy myth." The most recent and detailed work about the anti-Jesuit myth is by Michel Leroy, Le mythe jésuite. De Béranger à Michelet (Paris: Presses Universitaires de France, 1992). For the particular case of Portugal, see José Eduardo Franco, O mito dos jesuítas em Portugal, no Brasil e no Oriente (séculos XVI a $X X)$ (Lisbon: Gradiva, 2006). On anti-Jesuitism see also: Pierre-Antoine Fabre and Catherine Maires, eds., Les Antijésuites. Discours, figures et lieux de l'antijésuitisme à l'époque moderne (Rennes: Presses Universitaires de Rennes, 2010).

2 Such is the opinion of the authors of the most complete and detailed accounts of Pombal's campaign: José Eduardo Franco and Christine Vogel, "Um acontecimento mediático na Europa das Luzes: A propaganda antijesuítica pombalina em Portugal e na Europa," Brotéria 169 (2009): 349-506; Christine Vogel, Der Untergang der Gesellschaft Jesu als europäisches medienereignis (1758-1773). Publizistische Debatten im Spannungsfeld von Aufklärung und Gegenaufklärung (Mainz: Verlag Philipp Von Zabern, 2006). 
The most important books published in this period—sometimes called "Pombal's anti-Jesuit catechisms" - were Relação abreviada (1757), Erros ímpios e sediciosos (1759), Dedução cronológica e analítica (1767-1768), and Compêndio histórico do estado da Universidade de Coimbra (1771). ${ }^{3}$ These works were translated and widely diffused in Europe and Asia: Relação abreviada, for instance, was translated into French, German, Spanish, and Italian; Dedução cronológica e analítica, besides being translated into French, Spanish, and Italian was also translated into Chinese because Pombal wanted it to be as "universal as the missionary labors of the Jesuits."4 Anti-Jesuitism was not only vigorously reinforced with these materials as it was also profoundly influenced by Pombal's arguments. This campaign and Pombal's diplomatic efforts were so significant during this period that, as already said, they played a non-negligible part in the expulsion of the Jesuits from other European countries—France (1764), Spain (1767), Two Sicilies (1767) and Parma $(1768)$ - and even in the papal suppression of the Society of Jesus in $1773 .{ }^{5}$

3 Relação abbreviada da republica, que os religiosos jesuitas das provincias de Portugal, e Hespanha, estabeleceraõ nos dominios ultramarinos das duas monarquias, e da guerra, que nelles tem movido, e sustentado contra os exercitos hespanhoes e portuguezes; formada pelos registos das secretarias dos dous respectivos principaes commissarios, e plenipotenciarios; e outros documentos authenticos (Lisbon: n.p., 1757); D. José I de Portugal, Erros impios e sediciosos, que os religiosos da companhia de jesus ensinaraõ aos reos, que foraõ justiçados, e pertenderaõ espalharnos póvos destes reynos (Lisbon: Officina de Miguel Rodrigues, impressor do Eminentíssimo Senhor Cardeal Patriarca, 1759); José Seabra da Silva, Deducão chronológica e analítica na qual se manifestão pela sucessiva serie de cada hum dos reynados da Monarquia Portuguesa, que decorrerão desde o Governo do Senhor Rey D. Jão III até o presente, os horrorosos estragos, que a Companhia denominada de Jesus fez em Portugal, e todos os seus domínios por hum plano, e systema por ella inalteravelmente seguido desde que entrou neste Reyno, até que foi delle proscripta, e expulsa pela justa, sabia, e providente Ley de 3 de Setembro de 1759 (Lisbon: Officina de Miguel Manescal da Costa, 1767-1768); Junta de Providencia Litteraria, Compendio historico do estado da Universidade de Coimbra no tempo da invasão dos denominados jesuitas e dos estragos feitos nas sciencias e nos professores, e directores que a regiam pelas maquinações, e publicações dos novos estatutos por eles fabricados (Lisbon: Regia Officina Typographica, 1771). On these works see also: José Eduardo Franco, "Os catecismos antijesuíticos pombalinos: As obras fundadoras do antijesuitismo do Marquês de Pombal," Revista Lusófona de Ciência das Religiões, 7/8 (2005): 247-68. Franco and Vogel, "Um acontecimento mediático," 351.

5 Pombal's influence and role in the expulsion of the Jesuits from different countries in Europe and in the suppression of the Society is well documented. For recent works on this topic see: Bertrand Roehner, "Jesuits and the State. A Comparative Study of their Expulsions (15901990)", Religion 27 (1997): 165-82; António Júlio Trigueiros, “'O negócio jesuítico' e o papel da política regalista portuguesa," Brotéria 169 (2009): 149-67. On the influence of the Pombaline literature on the politicians who expelled the Jesuits from Spain see: Enrique Giménez López, 
The campaign designed by the Marquis of Pombal was built upon three major theses. The first thesis claimed that the Jesuits had uncontrolled power, especially overseas where they were building "a state within the state." One of the main accusations was that they were profiting illegally from commerce with the missionary province of the state of Grão-Pará and Maranhão (roughly today's northern Brazil). When a state-controlled trade company was created in June 1755 - the Companhia do Comércio do Grão-Pará e Maranhão-the relations between the Jesuits and the governor of Grão Pará and Maranhão, Francisco Xavier de Mendonça Furtado (1701-1769), who was Pombal's brother, immediately deteriorated. ${ }^{6}$ The newly founded company was granted the monopoly of exports and sea commerce, and its foundation led to first episodes of open conflict between Pombal and the Jesuits. ${ }^{7}$ The conflict rapidly escalated because — as the Jesuits claimed — the monopoly of the Companhia do Grão-Pará e Maranhão delivered a death blow to the Jesuit missions and colleges in Brazil, whose economic survival was dependent on the trading of Brazilian goods.

The second thesis was that the Jesuits were involved in the attempted murder of king Dom José (1714-1777) on September 3, 1758. Prominent members of the aristocracy - the Marquis and Marchioness of Távora, the duke of Aveiro and the count of Atouguia - were held responsible and executed in Lisbon on January 13, 1759, but the Jesuits were also considered to be involved in the plot

"Portugal y España ante la extinción de los jesuitas," in Los jesuitas españoles expulsos. Su imagen y su contribución al saber sobre el mundo hispánico en la Europa del siglo XVIII, ed. Manfred Tietz (Madrid-Frankfurt am Main: Iberoamericana-Vervuert, 2010), 337-57; Enrique Giménez López, "El antijesuitismo en la España de mediados del siglo XVIII," in Fénix de España. Modernidad y cultura propia en la España del siglo XVIII (1737-1766). Homenaje a Antonio Mestre Sancís, ed. P. Fernández Albaladejo (Madrid: Marcial Pons, 20o6), 283-326; Mar García Arenas, "La Compañía de Jesús en la Deducción cronológica y analítica pombalina", Revista de Historia Moderna - Anales de la Universidad de Alicante 21 (2003): 315-48. On the expulsion and exile of the Portuguese Jesuits see also the recent work: Maria Grazia Russo and António Júlio Limpo Trigueiros, SJ, I Gesuiti dell'Assistenza Lusitana esiliati in Italia (1759-1831) (Padova: CLUEP, 2013).

6 For a more detailed account see Dauril Alden, "The Gang of Four and the Campaign against the Jesuits in Brazil," in Jesuits II. Cultures, Sciences and the Arts, 1540-1773, eds. John O'Malley et al. (Toronto: University of Toronto Press, 2006), 707-24.

7 As a consequence of these polemics, the Jesuits were expelled from the court in 1757-a first clear sign of the storm that was mounting against the Society in Portugal. It might be noted that Pombal's involvement in this company was not wholly uninterested since he held shares, purchased on behalf of his second wife, Leonor Ernestina (1721-1789), countess of Daun. See: Domingos Maurício S.J., "Pombal e a Companhia do Grão-Pará e Maranhão," Brotéria 80 (1965): $743^{-50 .}$ 
(see figure 1). ${ }^{8}$ Besides triggering the expulsion of the Jesuits, this accusation also led to the execution of Father Gabriele Malagrida (1689-1761), who was judged to have personally participated in the assassination attempt. ${ }^{9}$

The third thesis was that the Jesuit educational system was profoundly deficient and that they were illiterate and scientifically backward. This accusation made explicit a set of critiques to Jesuit education and teaching methods that had been gaining momentum since the early decades of the eighteenth century. ${ }^{10}$ Although similar criticism had erupted in other countries in Europe, Pombal sharpened what was mostly a vague animosity into a very specific accusation: not only were the Jesuits culturally and scientifically incompetent and obsolete but they had also become the main obstacle to "progress" and to scientific development of Portugal. ${ }^{11}$ By cleverly playing with the perceived

8 These public executions, carried out with extreme barbarity, sent shock waves through Europe and revealed the darker side of Pombal's personality. See: Marquês de Alorna, As prisões da Junqueira durante o ministério do marquês de Pombal (Lisbon: Typographia Universal, 1857) [2 $2^{\text {nd }}$ edition, Lisbon: Typographia Universal, 1882]; César da Silva, A execução dos Távoras (Lisbon: João Romano Torres, 1921); Manuel João Gomes, ed., O processo dos Távoras: a expulsão dos jesuítas (Lisbon: Editora Afrodite, 1974). The literature on the Marquis of Pombal, his personality, and his policies is immense. See especially the recent works: Kenneth Maxwell, Pombal, Paradox of the Enlightenment (Cambridge: Cambridge University Press, 1995); Nuno Gonçalo Monteiro, D. José. Na sombra de Pombal (Lisbon: Temas e Debates, 2008); Nuno Gonçalo Monteiro, "Pombal's Government: Between Seventeenth-Century Valido and Enlightened Models," in Enlightened Reform in Southern Europe and its Atlantic Colonies, c. 1750-1830, ed. Gabriel Paquette (Farnham and Burlington: Ashgate, 2009), 321-38.

9 Malagrida was burned at the stake in an auto de fé on September 20, 1761. On Malagrida see: Paulo Mury, S.J., História de Gabriel Malagrida da Companhia de Jesus, trans. Camilo Castelo-Branco (Lisbon: Livraria Editora de Mattos Moreira, 1875); Processo do padre Gabriel Malagrida, Arquivo Nacional da Torre do Tombo, Tribunal do Santo Ofício, Inquisição de Lisboa, proc. 8064; Sommervogel, V, 394-95.

10 A very heated polemic around Jesuit teaching methods and pedagogy erupted in Portugal after the publication of the book by Luís António Verney, Verdadeiro método de estudar, para ser útil à républica, e à igreja: proporcionado ao estilo, e necesidade de Portugal (Valença: Antonio Balle, 1746) [reprint, Porto: Domingos Barreira, 1984].

11 Interestingly, in recent years a wealth of studies has been focused on Jesuit scientific activities in Portugal: Henrique Leitão and Lígia de Azevedo Martins, eds., Sphaera mundi: A ciência na "Aula da esfera". Manuscritos científicos do Colégio de Santo Antão nas colecções da BNP (Lisbon: Biblioteca Nacional de Portugal, 2008); Henrique Leitão, A ciência na Aula da Esfera no Colégio de Santo Antão, 1590-1759 (Lisbon: Comissariado Geral das Comemorações do V Centenário do Nascimento de S. Francisco Xavier, 2007); Luís Carolino and Carlos Ziller Camenietski, eds., Jesuitas, ensino e ciência (Casal de Cambra: Caleidoscópio, 2005); Luís Saraiva and Catherine Jami, eds., History of Mathematical 


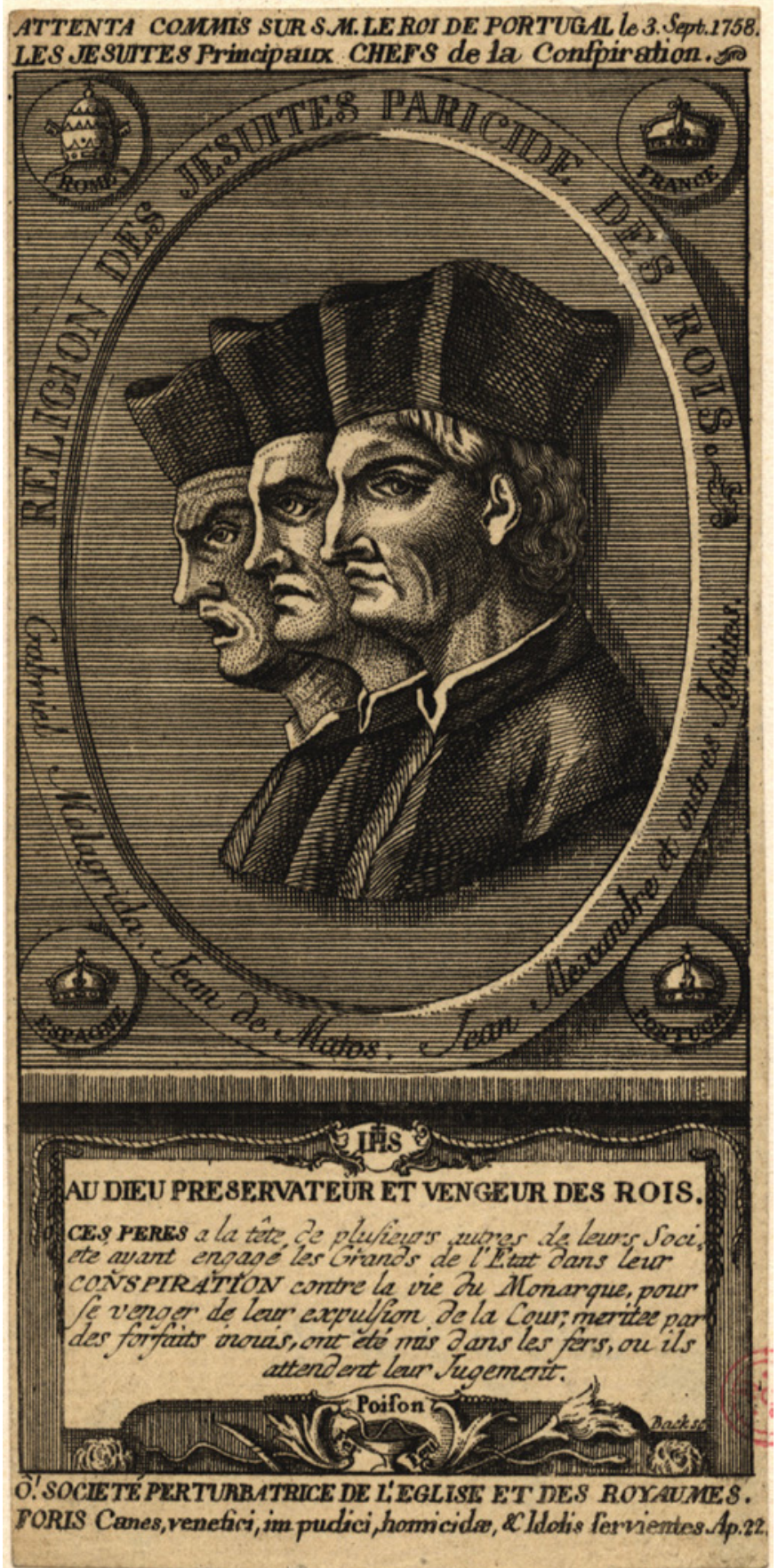

FIGURE 1 A caricature that portrayed three Jesuits as "paricide des rois," c. $1758-1761$. COURTESY OF BIBLIOTECA NACIONAL DE PORTUGAL. 
notion of Portugal's "decadence" from its sixteenth-century imperial grandeur, Pombal identified the Jesuits as the guilty party. He was thus brilliantly adjusting to Enlightenment perceptions that equated modernity with scientific progress. The consequence followed with implacable logic: the Jesuits' impressive network of colleges was, after all, the main obstacle to progress and the root of all Portugal's woes; its extraction from the country was not only necessary but even desired.

The first two theses were the most decisive triggers for the expulsion. The second argument was actually the proximate cause, and the Jesuits were expelled exactly one year after the royal assassination attempt-a very symbolic timing. But these two arguments were also circumstantial, built around a specific set of historical events. It was the third one, broader and more abstract, that turned out to be the more durable and, in a sense, the one that most deeply affected the image of the Society of Jesus in Portugal and thus conditioned its future.

After the expulsion, Pombal was especially interested in developing the accusation of Jesuit educational backwardness and scientific illiteracy. With the Society now out of the stage, Pombal was virtually unhindered to mount in painstaking detail a devastating narrative to show that the consequences of the Jesuit presence in Portugal had been disastrous. By doing so, he expected to provide a theoretical background that justified his decision to expel the Society while at the same time announcing in shining prose his unlimited dedication to the progress, modernization, and development of the country. What he could have not predicted was that he was putting in place a critique that would prove to be extremely resilient to the point of affecting the return of the Society a century later.

Pombal's gradual construction of a complex and detailed argument emerges clearly from a closer inspection of the four major anti-Jesuit works promoted by him. Relação abreviada (1757), a highly political report ( 85 p.) printed in the immediate aftermath of the complex quarrels in Brazil, and Erros ímpios e sediciosos (1759), a thirty-two-page booklet that accused the Jesuits of being supportive of regicides and that was printed after the attempted murder of the king, were relatively short and focused works; they did not address the educational or

Sciences: Portugal and the East Asia, III. The Jesuits, the Padroado and East Asian Science (1552-1773) (Singapore: World Scientific, 2008); Luís Saraiva, ed., History of Mathematical Sciences: Portugal and East Asia, II. Scientific Practices and the Portuguese Expansion in Asia, 1498-1759 (Lisbon: CMAF-UL, 2001); Luís Saraiva, ed., History of Mathematical Sciences. Portugal and East Asia, I. História das Ciências Matemáticas: Portugal e o Oriente (Lisbon: Fundação Oriente, 200o). 
cultural issues and much less any scientific ones. ${ }^{12}$ After the expulsion, however, Pombal's arguments changed considerably in content, detail, and dimension: Dedução cronológica e analítica (1767-1768) and Compêndio histórico (1771) were extremely ambitious works, much more intricate and much more voluminous than the first two anti-Jesuit treatises.

Dedução cronológica e analítica was a monumental enterprise, published originally in three volumes (a total of 1,387 pages). It was, by far, the longest, most complex, and most influential piece of anti-Jesuit propaganda ever published in Portugal (see figure 2) $\cdot{ }^{13}$ Its objective was to provide an ample and detailed picture of the history of Portugal demonstrating the catastrophic effects of the arrival and the presence of the Society of Jesus from the midsixteenth century onwards. While the first part dealt with the political history of the Portuguese empire, and implied that the Jesuits caused the institutional decadence of the monarchy, the second part accused them of being responsible also for the decline of the church's institutions. ${ }^{14}$

According to this work, Portugal's "generalized idiocy" of present times had only one cause: the "fateful arrival" of the Jesuits. ${ }^{15}$ They were accused of destroying the best schools (for example, a celebrated Colégio das Artes, that had been founded in Coimbra in 1547), and of ruining the University of Coimbra, which they "subdued, prostituted, and darkened."16 The allegations ran wild and the Jesuits, which had "no weapons apart from their impostures," were actually accused of establishing a "tyrannical empire" that had been "such a terrible scourge for the Crown, the Arts, the Armory, the Commerce, and the Agriculture for more than two centuries in these Realms and all their Dominions." ${ }^{17}$

Compêndio histórico was the second largest "anti-Jesuit catechism" (494p.). Despite being much less extensive and ambitious than the Dedução cronológica e analitica, the work was crucial in the construction of a specific cultural and

12 Franco and Vogel, “Um acontecimento mediático," 354-61.

13 Although the work indicates José Seabra da Silva as its author, it is clear today that Carvalho e Melo personally directed it: Franco and Vogel, "Um acontecimento mediático," 363-64.

14 Ibid., $361-68$.

15 The "generalized idiocy" [geral idiotismo] was caused by the "funestissima entrada dos Regulares da Companhia chamada de Jesus nestes Reynos, e todos os seus Dominios: Porque desta originaria, e atrocissima causa vierão a seguir-se todas as outras, que produzirão nestes Reynos aquelle geral idiotismo." Silva, Dedução cronológica e analítca, 2: IV.

16 Silva, Dedução cronológica e analítca, 2: V.

17 Ibid., 1: I. 


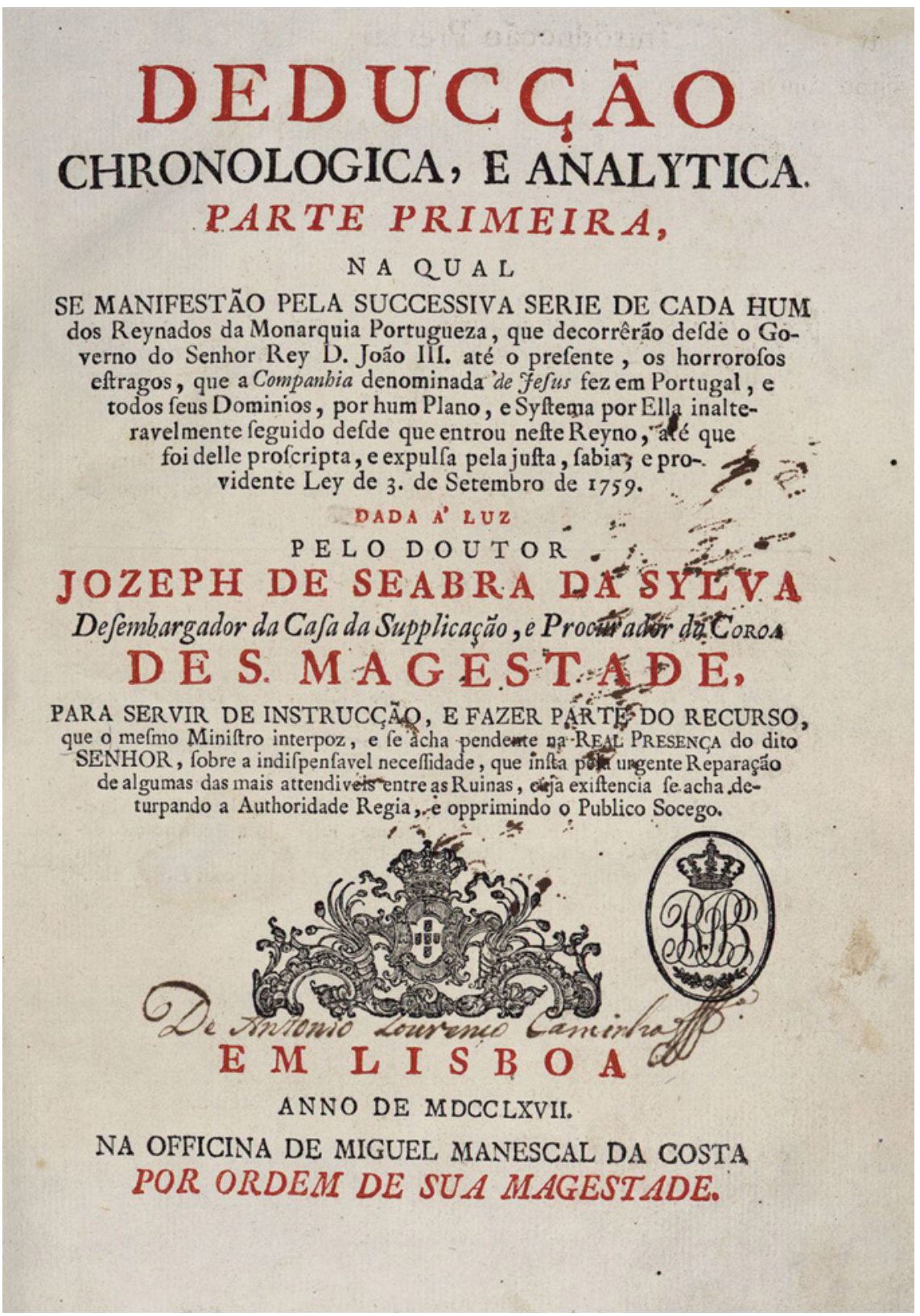

FIGURE 2 Frontispiece of the first volume of Dedução cronológica e analítica, 1767. COURTESY OF BIBLIOTECA NACIONAL DE PORTUGAL. 
educational argument directed against the Jesuits. The book was focused on documenting and explaining the "decadence" of the University of Coimbra. The central accusation was that the Jesuits ruined the university and "buried the Portuguese monarchy in the darkness of ignorance."18 After censuring the Jesuits for having corrupted the teaching of theology and of both canon and civil law, it proceeded with a severe critique of the teaching of medicine, which, like the other subjects, was declared to be "flourishing" before the Jesuit's arrival. ${ }^{19}$ The decadence of medicine was presented as a consequence of scientific backwardness, which in turn was attributed to the "poisonous root" of "Scholastic physics." The Jesuits were also accused of having "buried true physics, philosophical chemistry, pharmaceutics, botany, and anatomy." ${ }^{20}$ In the almost five hundred pages of the Compêndio histórico Jesuits were continuously castigated for promoting ignorance, stupidity, backwardness, and rigid conservatism; the accusation that they opposed science and everything modern was fully argued in detail.

2

\section{Pombal's Educational Reform and Its Outcome}

Having eliminated the Society of Jesus and its schools in Portugal, Pombal proceeded to implant his own educational system. It is to this new reality that our attention must now be briefly directed.

It is unquestionable that the statutes and teaching programs of the Pombaline reform display a genuine desire of scientific and educational modernity, deeply informed by Enlightenment ideals. ${ }^{21}$ However, it is also

18 Compêndio histórico, IX. The preface, which was signed by nine prominent politics and clerics (including Marquis of Pombal, bishop of Beja, Cardinal Cunha, José de Seabra da Silva, and Francisco de Lemos de Faria, rector of the university), summarized the main accusations against the Jesuits.

19 Ibid. The "damages" in the study of theology and law are the subject of chapters I and II respectively.

20 Ibid., XII. The "damages" in medicine are described in chapter III. It bears reminding that the Jesuits were never in charge of the University of Coimbra, that they never had administrative tasks there, and that their relations with the university were often strained. The Society of Jesus was only in charge, after 1551, of the Colégio das Artes-a pre-university school—and only very few Jesuits actually taught at the university.

21 There are some fine scholarly studies of Pombal's educational policies: António Alberto Banha de Andrade, A reforma pombalina dos estudos secundários (1759-1771). Contribuição para a história da pedagogia em Portugal (Coimbra: Universidade de Coimbra, 1981); 
beyond question that any sensible evaluation of Pombal's reformist efforts must balance what the letter of laws, statues, and curricula stated with what was really put into action. Any serious attempt at assessing Pombal's educational policies must therefore go beyond a mere analysis of the normative corpus and look into the decisions that were actually taken and the events that really took place. Such a type of enquiry is frequently not pursued, and historians many times seem content in extolling the unquestionable modernity of Pombal's official documents and declared intentions. A thorough and detailed study of the reform in education promoted by the Marquis of Pombal is not our aim here, but a few statistical data and the selection of well-established findings by historians of education in Portugal are enough for our purposes.

Before the expulsion in 1759, the Society of Jesus was in charge of one university (Évora) and thirty-seven colleges in the Portuguese empire. ${ }^{22}$ Let us look first at pre-university education, that is, the colleges. The first point to note is that Pombal deliberately avoided to use the quite large infra-structure of the Jesuit colleges: only five of the former Jesuit schools were reused for educational purposes. This clearly signaled a break with the Jesuit past, but it was a rather cost-ineffective decision. The changes in total number of students are even more surprising. In 1759, the Jesuits were responsible for the education of about twenty thousand pre-university students in Portugal. Precise numbers are perhaps impossible to determine, but this order of magnitude is surely the correct one. ${ }^{23}$ In the immediate aftermath of the expulsion, and as

Como interpretar Pombal? No bicentenário da sua morte (Lisbon: Brotéria, 1982); Rómulo de Carvalho, História do ensino em Portugal. Desde a fundação da nacionalidade até ao fim do regime de Salazar-Caetano (Lisbon: Fundação Calouste Gulbenkian, 1986); História da Universidade em Portugal, 3 vols., (Coimbra-Lisbon: Universidade de Coimbra-Fundação Calouste Gulbenkian, 1997); Ana Cristina Araújo, ed., O Marquês de Pombal e a universidade (Coimbra: Universidade de Coimbra, 2000.)

22 In 1759, the Jesuits directed sixteen colleges in Portugal, one in Madeira, three in Azores, twelve in Brazil, one in Angola, three in India, and one in Macao: Joaquim Veríssimo Serrão, História de Portugal, vol. VI (Lisbon: Verbo, 1982), 254. See also Manuel Antunes S.J., "O Marquês de Pombal e os jesuítas," in Como interpretar Pombal?, 25-142; António Júlio Trigueiros, S.J., "A expulsão e exílio dos jesuítas de Évora em 1759," in Universidade de Évora (1559-2009). 450 anos de modernidade educativa, ed. Sara Marques Pereira and Francisco Lourenço Vaz (Lisbon: Chiado Editora, 2012), 357-78.

23 The estimate was established by António Leite, S.J., "Pombal e o ensino secundário," in Como interpretar Pombal?, 165-81, here 171. For a more detailed discussion on this estimate see: Francisco Malta Romeiras, "Das ciências naturais à genética. A divulgação científica na revista Brotéria (1902-2002) e o ensino científico da Companhia de Jesus nos séculos XIX e XX em Portugal" (PhD diss., University of Lisbon, 2014), 13-23. See also 
an historian of education put it, this number dropped abruptly, creating "an almost total void in the field of educational activities."24 The Jesuit school network was not replaced by anything remotely comparable; in absolute number of students, Pombal's secondary education system was only a very small fraction of what the Jesuits had been able to achieve. To put matters in their proper-and dark - perspective, it might be added that statistics show that the number of twenty thousand pre-university students was only reached again in Portugal in the 1930s, that is, more than 170 years after the Society had left. ${ }^{25}$ Furthermore, historians of education agree that besides the massive decrease of students, there was also an evident debasing of quality: simplification of the courses' contents, reduction in their length, decrease in the number of schools where Latin was taught, unprepared teachers, etc. ${ }^{26}$

The most emblematic of all schools created by the Pombaline educational reform was the Real Colégio dos Nobres, a college accepting only young noblemen that was established in 1761 in Lisbon. ${ }^{27}$ The college was not only radically class-selective; it was also very small, hosting a maximum of one hundred students. Again, to put matters into perspective, one need only to remember that the most important Jesuit college in Lisbon, the Colégio de Santo Antão, usually had more than two thousand students each year, in some periods reaching around three thousand. The modern and ambitious statutes of the Real Colégio dos Nobres determined that in addition to intense schooling in the humanities (with classes of Latin, Greek, French, Italian, English, rhetoric, poetry, etc.)

Francisco Rodrigues S.J., A formação intellectual do jesuita (Porto: Livraria Magalhães \& Moniz, 1917), 168-70.

24 Rómulo de Carvalho, "As ciências exactas no tempo de Pombal," in Como interpretar Pombal?, 215-32, here 215.

$25 \quad 193^{-1932}$ was the first academic year since 1759 for which more than twenty thousand students enrolled in private or public schools in Portugal are documented. However, it was only in 1935-1936 that the public schools alone hosted more than twenty thousand students. A more detailed analysis must also take demographic growth into consideration. In 1758, Portugal had a population of approximately 2,533,000 inhabitants, and in the 1930s this ascended to $6,802,429$ inhabitants. Thus, in proportional terms, the population of pre-university students in the 1930 s was still very far from its value in 1759 . For more details on the statistical data see: Jorge Ramos do Ó, Ensino liceal (1836-1975) (Lisbon: Ministério da Educação, 2009), 40, 45; Teresa Ferreira Rodrigues et al., História da população portuguesa. Das longas permanências à conquista da modernidade (Porto: CEPESE Afrontamento, 2008), 253, 511.

26 Andrade, A reforma pombalina, 897.

27 Estatutos do Collegio Real de Nobres da corte e cidade de Lisboa (Lisbon: Officina de Miguel Rodrigues, 1761), 775. See also Rómulo de Carvalho, História da fundação do Colégio Real dos Nobres de Lisboa (Coimbra: Atlântida - Livraria Editora, 1959). 
pupils could also opt for training in scientific disciplines. The scientific course, with a rich variety of disciplines (arithmetic, geometry, trigonometry, algebra, infinitesimal analysis, mechanics, hydraulics, optics, astronomy, military and civil architecture, and experimental physics) was, in effect, the truly emblematic novelty of the college. The reality, however, was nothing but an unmitigated failure: in its whole history only seven students took the scientific disciplines. The leading expert in the history of this college notes the complete "uselessness of scientific education." 28

As for the reform of the university, the picture is also dramatic. To simplify matters let us omit the facts regarding the Jesuit university in Évora, which was simply shut down, and concentrate only on the University of Coimbra. The new statutes (1772) reflect undoubtedly a genuine desire of modernity, higher academic standards, and increased attention to scientific matters. To focus only on the scientific aspects, it must be mentioned that a new faculty of mathematics was created, the experimental teaching of science was promoted, and modern facilities such as a botanical garden, an astronomical observatory, a physics cabinet, a chemistry laboratory, and a museum of natural history were planned. But, once again, a more attentive look at the reality reveals a rather depressing result, as the statistics bluntly show. In the five decades before the reform, more precisely between 1724 and 1771, an average of 2,827 new students enrolled each year at the University of Coimbra. After the reform, in the years between 1772 and 1820 , this number dropped to an average of $45^{2}$ new students per year-a dramatic reduction of eighty-four per cent, which explains why some scholars label the phenomenon an educational "catastrophe."29

Any serene comparison between the intentions of Pombal's reform, as stated in its foundational documents and texts, on the one hand, and the starkness of reality, on the other, cannot fail to notice the shocking imbalance between what was proposed and what was actually being put into practice. As one of the most distinguished historians of education in Portugal put it: "the monumentality of the [Pombal's educational reform] project was rather staged."30

28 Carvalho, "As ciências exactas no tempo de Pombal," 217.

29 Despite being already an impressive figure, this value does not contemplate the extinction of the University of Évora [Universidade de Évora] which the Jesuits directed from 1559 to 1759 . Since 320 new students enrolled at the University of Évora in 1758 , the total decrease in university enrolments amounts to a staggering eighty-six per cent. For full bibliography and discussion of these numbers see Romeiras, "Das ciências naturais à genética," 21-22.

30 Rómulo de Carvalho, História do ensino em Portugal: desde a fundação da nacionalidade até ao fim do regime de Salazar-Caetano (Lisbon: Fundação Calouste Gulbenkian, 1986), 466. 
Although rhetorical exaggerations are known to usually taint Pombal's documents, some explanation must be sought if one wants to understand the drastic imbalance between programs and reality. First of all, one cannot deny that despite the great resources he had at his disposal, Pombal was operating in quite adverse economic circumstances. The country had been severely affected by the earthquake of 1755 and was facing serious financial difficulties that certainly hindered Pombal's plans. Secondly, and perhaps more importantly, Pombal's programmatic texts may easily be misunderstood by the modern reader. Despite his constant peroration about modernization, development, and education, Pombal never intended generalized education or similar. On the contrary, to him, as to the Enlightenment intellectuals that had inspired his ideas, education was mostly an élite affair. ${ }^{31}$ Hence, the "paradox" of Pombal's educational reform - the impulse for modernization coupled with a drastic reduction of students - might not be that paradoxical at all.

Be that as it may, in one aspect Pombal clearly achieved his objectives: after him, the image of the Society of Jesus was hopelessly associated with educational obsolescence, scientific obscurantism, and obstacle to progress.

\section{The Return of a Stubborn Accusation}

In 1858, ninety-nine years after the expulsion, Carlos Rademaker, S.J. (18281885) restored the Society of Jesus in Portugal. ${ }^{32}$ Despite the large time gap, the Pombaline argument that made the Jesuits responsible for Portugal's "decadent" state and the "generalized idiocy" of the country still haunted the Society of Jesus. Very much aware of the unusual longevity, influence, and the wide acceptance of this accusation, the Jesuits realized that their return was to take place in an adverse cultural environment. In order to regain the vigor and influence they had had in previous centuries, they were forced to counter the effects of this stubborn accusation. This necessity, together with nineteenthcentury scientistic ideals, shaped in quite visible ways their new apostolates and initiatives. Indeed, the teaching and practice of science acquired a rather

31 The foundation of Real Colégio dos Nobres was based on a doctrine of a Portuguese physician, António Ribeiro Sanches, who defended that only noblemen could study. He thought that if commoners studied, some smaller offices would disappear, because literate children would not want to pursue their fathers' labors. The most important work defending this view is António Ribeiro Sanches, Cartas sobre a educação da mocidade (Cologne: n.p., 176o) [reprint, Porto: Domingos Barreira, n.d.].

32 For a detailed account of the restoration of the Society of Jesus in Portugal see: Romeiras, "Das ciências naturais à genética," $36-99$. 
unusual prominence in the cultural and educational activities of the Jesuits in the decades after their return. Scientific activities were put at the front of their educational priorities, and the engagement with science played an important role in the way they projected their public image.

Upon their return to Portugal, the Jesuits founded two colleges, the Colégio de Campolide (1858-1910) in Lisbon and the Colégio de São Fiel (1863-1910) in Louriçal do Campo, a small town in the interior of Portugal. These colleges targeted quite different sectors of society, with the Lisbon college being directed mostly to the instruction of the higher bourgeoisie and aristocrats, and the Colégio de São Fiel to a lower rank, countryside bourgeoisie. However, in both of them a rather similar dedication to science was pursued. This attention to scientific matters greatly exceeded the official requirements and what was by then the usual practice in the state schools. That is, these colleges immediately distinguished themselves among the other pre-university institutions in Portugal. In both colleges, the Jesuits created chemistry and physics laboratories equipped with modern instruments, and hands-on experimental science became the norm. They organized excellent natural history collections, promoted scientific expeditions with their students, subscribed to scientific journals, and corresponded with the scientific community in Portugal.

Following Jesuit tradition, scientific academies were created in the colleges where the most talented students engaged in advanced studies, discussions, and in the performing of modern experiments. ${ }^{33}$

Some of the teachers engaged in original research, mainly in botany, zoology, and physics, and to a considerable extent they even tried to replicate the organization and tasks of true scientific institutions. ${ }^{34}$ Jesuit teachers and some students systematically collected meteorological data, which they then shared with other Portuguese scientists. In some instances, truly exceptional activities were carried out. One of the teachers of the Lisbon college, Father António Oliveira Pinto, S.J. (1868-1933), earned a notorious place in the history of physical science in Portugal: he was an active promoter of modern experimental science, performing some of the first experiments with telegraphy

33 On these academies see Romeiras, "Das ciências naturais à genética," 106-31.

34 For a detailed description and discussion of the scientific activities developed in these colleges, see Romeiras, "Das ciências naturais à genética," 100-49; Francisco Malta Romeiras and Henrique Leitão, "Jesuítas e ciência em Portugal. III. As expedições científicas e as observações dos eclipses solares de 1900 e 1905," Brotéria 174 (2012): 227-37; Francisco Malta Romeiras and Henrique Leitão, "Jesuítas e ciência em Portugal. II. Carlos Zimmermann, S.J. e o ensino da microscopia vegetal," Brotéria 174 (2012): 113-25. 
(1902) and the first recorded experiments with radioactive materials (1910) at the Colégio de Campolide. ${ }^{35}$

One of the most remarkable initiatives of the Jesuit teachers, a direct consequence of the fact that some of them were doing original and relevant scientific work, was the founding of Brotéria, a journal dedicated mainly to botany and zoology. Founded in 1902 by three teachers of the Colégio de São Fiel who had been involved in research in the natural sciences-Joaquim da Silva Tavares, S.J. (1866-1932), Cândido Azevedo Mendes, S.J. (1874-1943), and Carlos Zimmermann, S.J. (1871-1950)—Brotéria started as a purely scientific periodical devoted to the publication of original research work. The journal lasted until 2002 and throughout its history published more than 1,300 research papers on zoology, botany, biochemistry, and molecular genetics. It acquired the indisputable status as one of the most relevant scientific journals in twentieth-century Portugal. Its unique status among Jesuit journals must also be noted since, unlike other well-known periodicals of the Society of Jesus, such as Razón y Fé, Civiltà Cattolica and Stimmen der Zeit, Brotéria was a strictly scientific research journal. ${ }^{36} \mathrm{~A}$ further point deserves notice. When referring to science in all their publications and texts, Jesuits in late nineteenth- and early twentieth-century Portugal do not seem to show any particular interest in the more philosophical aspects of scientific pursuits nor in entering the polemics around the conflict between science and faith popularized by John Draper (1811-1882) and Andrew White (1832-1918) in the nineteenth century. They were instead especially keen in producing relevant science and in showing that they were capable of doing it.

The Jesuits were very conscious of the need to project a public image as firstrate scientific educators and even as truly modern and up-to-date scientists. They did it in different ways, the most spectacular being the public sessions organized at the colleges where the students of the scientific academies discussed some scientific topics and performed demonstrations. The scientific sessions at the Colégio de Campolide in Lisbon became noted social events,

35 Francisco Malta Romeiras and Henrique Leitão, "Jesuítas e ciência em Portugal. I. António Oliveira Pinto, S.J. e as primeiras experiências com radioactividade em Portugal," Brotéria 174 (2012): 9-20.

36 On the scientific history of Brotéria see Romeiras, "Das ciências naturais à genética," 173-309; Francisco Malta Romeiras, "The Emergence of Molecular Genetics in Portugal. The Enterprise of Luís Archer S.J.," AHSI 164 (2013): 501-12; Francisco Malta Romeiras, "The Journal Brotéria (1902-2002): Jesuit Science in the $20^{\text {th }}$ Century," Journal of History of Science and Technology 6 (2012): 100-9; Francisco Malta Romeiras and Henrique Leitão, "Jesuítas e ciência em Portugal. IV. A revista Brotéria - Sciencias Naturaes e a sua recepção nacional e internacional," Brotéria 174 (2012): 323-33. 
attended by Lisbon's higher society and in some cases even by members of the royal family. 37

This strong commitment to scientific teaching and to the practice of science allowed the Society of Jesus to acquire a much-desired credibility, at least in some quarters of Portuguese society. Jesuit colleges rapidly became noted for the quality of the teaching and attracted the sons of the wealthiest and most influent families. Of particular importance was the praise the Jesuits garnered from some of the most prominent Portuguese scientists. A notable case was that of Dr. Egas Moniz (1874-1955), a former student at the Colégio de São Fiel who won a Nobel Prize in medicine and physiology in 1949 and always praised the scientific training he had acquired with the Jesuits. ${ }^{38}$

Yet, despite all the efforts, Jesuit attempts at securing prominent positions as modern educators, advanced scientific teachers, and contributors to progress, proved insufficient. In 1910, during the republican revolution, when they were expelled again, the old Pombaline accusation reappeared once more in full force. ${ }^{39}$

Since the mid-nineteenth century, Portugal had been disturbed by religious quarrels. ${ }^{40}$ These controversies reflect the profound anticlericalism that can be felt in the works and speeches of famous politicians of the period, and in the public interventions and texts of influent writers, poets, and even physicians ${ }^{41}$ In these works, the most frequent subjects under discussion were the temporal power of the church, ultramontanism, the separation of church and state, religious conspiracies, obscurantism, and-most of all—anti-Jesuitism in a

37 Romeiras, "Das ciências naturais à genética," 110-23.

38 António Egas Moniz, A nossa casa (Lisbon: Paulino Ferreira Filhos Lda, 1950), 254.

39 For a detailed discussion of the expulsion of the Jesuits in the republican revolution see: Romeiras, "Das ciências naturais à genética," 149-70; Francisco Malta Romeiras and Henrique Leitão, "Jesuítas e ciência em Portugal. V. Os colégios de Campolide e de São Fiel e a implantação da República," Brotéria 174 (2012): 425-40.

40 On the many religious polemics of the period and nineteenth-century religious history in Portugal, see: Manuel Clemente and António Matos Ferreira, eds., Religião e secularização (Lisbon: Círculo de Leitores, 2002); Manuel Clemente, Igreja e sociedade portuguesa. Do liberalismo à República (Porto: Assírio \& Alvim, 2012); Luís Machado de Abreu and José Eduardo Franco, eds., Ordens e congregações religiosas no contexto da I Repúbica (Lisbon: Gradiva, 2010); Luís Machado de Abreu, Ensaios anticlericais (Lisbon: Roma Editora, 2004).

41 Some of the most relevant personalities were Adolfo Coelho (1847-1919), Antero de Quental (1842-1891), Guerra Junqueiro (1850-1923), Miguel Bombarda (1851-1910), Sampaio Bruno (1857-1915), and Teófilo Braga (1843-1924). For a detailed discussion and complete bibliography see Abreu, Ensaios anticlericais. 
particularly virulent form that "persistently monopolized the focus of anticlerical speeches." ${ }^{22}$ One of the most common themes put forward was the rather simplistic argument that there was a clear conflict between liberty, progress, and science on the one hand, and clericalism on the other hand. In essence, these works constantly stated that "who believes [in God] does not think, and who thinks does not believe."43 Needless to say, to late nineteenth-century anti-clericals, the Jesuits were the main culprits in the propagation of "non-thought."

Anti-Jesuitism thus occupied a very significant place at the core of the more general anti-clericalism of the period. There were many examples of books, journals, meetings, and even political rallies especially devoted to attack the Society of Jesus; ${ }^{44}$ the accusations of obscurantism and the conviction that Jesuits promoted "stupidity" were typical. Following Pombal's line of reasoning, the Jesuits were accused of kidnapping children and of enrolling them in a "dark seminary" which transformed them into "stupid night-birds."45 Manuel Borges Grainha (1862-1925), perhaps the most active and vocal anti-Jesuit critic in late nineteenth-century Portugal, was deeply influenced by Pombal's arguments and repeatedly insisted on the lack of quality of Jesuit schools and the backwardness of their teaching.

Perhaps noticing the irony of trying to appear modern while at the same time resorting to an argument that was more than a century old, some of the critics made a curious update of Pombal's accusations. They conceded that Jesuits might have been learned in the sixteenth and seventeenth centuries, but that at present they were definitely neither learned nor wise. ${ }^{46}$ Together with the depiction of Jesuits as manipulative and scheming clerics, always obsessed with power, the accusation of "backwardness" and the promotion of "stupidity" were structurally implanted in anti-Jesuitism at this period. ${ }^{47}$

42 Abreu, Ensaios anticlericais, 53.

43 "Quem crê não pensa, e quem pensa não crê." Manuel Joaquim de Carvalho Júnior, Nem Deus, nem Diabo. Solução da philosophia positiva (Lisbon:Typographia Elzeviriana, 1884), 7 .

44 António de Araújo, Jesuítas e antijesuítas no Portugal republicano (Lisbon: Roma Editora, 2004), 10.

45 Abílio Guerra Junqueiro, "Como se faz um monstro," in A velhice do padre eterno (Porto: Livraria Minerva, 1885), 65-69.

46 Manuel Borges Grainha, Os jesuitas e as congregações religiosas em Portugal nos ultimos trinta annos (Porto: Empreza Litteraria e Typographica, 1891), 145-66.

47 Besides publishing Os jesuitas e as congregações religiosas em Portugal nos ultimos trinta annos (Porto: Empreza Litteraria e Typographica, 1891), Manuel Borges Grainha printed several other anti-Jesuit works such as O Portugal jesuita (Lisbon:Typographia e Sterotypia Moderna, 1893). One of his most important works is História do Colégio de Campolide da Companhia de Jesus (Coimbra: Imprensa da Universidade de Coimbra, 1913). 
That the roots of late nineteenth-century anti-Jesuitism lie in Pombal's arguments becomes quite clear when examining the political speeches at the two houses of Portugal's parliamentary system at the time, the lower Câmara dos Senhores Deputados and the higher Câmara dos Dignos Pares do Reino. ${ }^{48}$ From 1882 to 1910, anti-Jesuit speeches were frequent in both houses and the memory of the Marquis of Pombal was often brought up. In 1882, while planning the centennial celebration of his death and the construction of a monumental bronze statue, some parliamentarians asserted that his greatest achievement had been the expulsion of the Jesuits, a feat for which he should have been entitled "liberator of the kingdom." For the deputy António da Cunha Belém, the expulsion of the Society of Jesus and the secularization of education were Pombal's most significant political acts. Implicitly-and sometimes explicitly-these parliamentarians agreed that the expulsion of the Jesuits had been a major step towards progress and development. Praise for Pombal's actions could be stretched to almost ridiculous proportions, as when a deputy suggested a parallel that amounted to a true atheist deification:

Just as they pray on the church of Saint Ignatius of Loyola on July 31, let us pray to Saint Sebastião José de Carvalho e Melo on the altar of the country and on the temple of freedom on May 8; let us canonize that figure and let us state, at least here, with heads held high, that the centennial celebration of the Marquis of Pombal also asserts that we worship him for being the grand statesman who expelled the Jesuits, because that expulsion was incontestably a step on the road to freedom. ${ }^{49}$

Nineteenth-century literature against the Jesuits explores a number of different topics - that they are hungry for power, interfere in politics, destroy family bonds, etc.-but never omits an attack to the quality of their teaching. However, the Jesuits' commitment to science did create some difficulties to the critics of the Society, forcing them to some intellectual contortions. In 1883, a report on the Colégio de São Fiel was published..$^{50}$ The existence of a modern and wellequipped physics cabinet and of a chemistry laboratory was noted, and the author had to direct his criticism to the teaching of history and philosophy,

48 Portugal had two Parliament houses, a system inspired in the British House of Commons and House of Lords, respectively.

49 Câmara dos Senhores Deputados, Sessão de 17 de Abril de 1882.

50 Joaquim Augusto de Sousa Refóios, O Collegio de São Fiel no Louriçal do Campo e o de Nossa Senhora da Conceição na Covilhã. Apontamentos sobre o jesuitismo no districto de Castello-Branco (Coimbra: Imprensa da Universidade de Coimbra, 1883). 
which he deemed highly "reactionary." In 1910, Pedro Ferrão published a book against the Jesuits voicing the usual accusations. ${ }^{51}$ He repeated the common charges of ambition, deceitfulness, and secrecy and insisted on the thesis of scientific and educational backwardness. But he felt the need of some justification and argued that the conviction that the Jesuits were learned and that their colleges were the finest teaching institutes was a false assumption, either ideological or uninformed. ${ }^{2}$

The contradictions of many of the accusations became obvious when it became public that several of the more prominent anti-Jesuit politicians chose the colleges of the Society for the education of their children. ${ }^{53}$ The hypocrisy of this position was explicitly denounced by the parliamentarian Tomás Ribeiro who lambasted Portuguese politicians for living a life of "constant lies" since they did the opposite of what they stood up for in the parliament and wrote in the press. ${ }^{54}$

Political events accelerated rapidly from 1907 to 1910 . Pressure by leading republican politicians as Afonso Costa (1871-1937), Miguel Bombarda (18511910) and António José de Almeida (1866-1929) increased as the demand for the expulsion of the Jesuits became more insistent. The Society of Jesus was judged to be illegal in Portugal because it infringed two laws that were still in force: the Pombaline decree of expulsion (1759) and the decree that banned all religious orders from Portugal (1834). In 1908 and 1909, Afonso Costa presented a bill to ban the Jesuits and close their colleges, but this would only occur on October 8,1910 , after the promulgation of his first decree as minister of justice of the new republic. ${ }^{5}$

\section{Conclusion}

On the morning of October 5,1910 , at the height of the republican revolution, the Colégio de Campolide was bombarded and then assaulted. ${ }^{56}$ In addition to the violence and humiliations toward the Jesuits, material loss was also tragic.

\footnotetext{
51 Pedro Ferrão, A educação jesuitica. O Collegio de S. Fiel. Subsidios para a historia contemporanea dos jesuitas (Lisbon: Guimarães \& C.A., 1910), 11.

52 Pedro Ferrão, A educação jesuitica, 79 .

53 Câmara dos Pares do Reino, Sessão de 10 de Junho de 1887.

54 Câmara dos Pares do Reino, Sessão de 15 de Junho de 1891.

55 Câmara dos Senhores Deputados, Sessão de 27 de Julho de 19o8; Sessão de 28 de Julho de 1909.

$5^{6}$ Luís Gonzaga de Azevedo, S.J., Proscritos (Valladolid: Florencio de Lara, 1911), I: 32-39.
} 
A considerable part of the college's scientific instruments, books, and collections was destroyed or robbed during the assault; what was not lost in that day was afterwards confiscated by the republican government. ${ }^{57}$ The Jesuits of Colégio de São Fiel were also imprisoned and humiliated. Their scientific instruments, books, and collections escaped unharmed, and were subsequently sent to the University of Coimbra and to public schools that lacked proper scientific equipment. ${ }^{58}$ The expulsion of the Jesuits and the confiscation of their scientific and educational assets created a commotion both nationally and internationally. Portuguese scientists, regardless of their religious beliefs or their allegiance to republican ideals, expressed their repugnance for such actions. ${ }^{59}$ In a telling demonstration of the scientific status that Portuguese Jesuits had at the time, the celebrated journal Science published a plea in favor of the Portuguese Jesuit naturalists, who by then had been exiled. ${ }^{60}$

57 Azevedo, Proscritos, I: 176.

58 On the republican revolution, the imprisonment of the Jesuits and the expropriation of their scientific assets, see Romeiras and Leitão, "Jesuítas e ciência em Portugal. V" 425-40; Romeiras, "Das ciências naturais à genética," 149-70.

59 Public denunciations came from the most famous Portuguese chemist, António Ferreira da Silva (1852-1923), founder and president of the Portuguese Chemistry Society [Sociedade Portuguesa de Química], and from Luís de Castro (1868-1928) and José Veríssimo de Almeida (1834-1915) both professors at the Agronomical Institute [Instituto Superior de Agronomia]. While the first two were close to the Jesuits and, most likely monarchists, Veríssimo de Almeida was a staunch republican and a freemason. On this matter see: D. Luís de Castro, "Protesto de homens de sciencias," Boletim da Associação Central da Agricultura Portuguesa 1, no. 5 (1912): 165-67; António Ferreira da Silva, "Director e redatores da 'Broteria.' Um appello aos homens de boa vontade," Revista de Chimica Pura e Applicada 6 (1910): 362-63; António Ferreira da Silva, "Os redactores da 'Broteria' exilados. As suas collecções scientificas confiscadas e perdidas," Revista de Chimica Pura e Applicada 7 (1911): 229-31; António Ferreira da Silva, "Broteria," Revista de Chimica Pura e Applicada 7 (1911): 377; António Ferreira da Silva, "Testemunho em favor da Brotéria," Brotéria-Vulgarização Científica 16 (1918): 190-91; António Ferreira da Silva, "Brotéria e os seus naturalistas," Revista de Chimica Pura e Applicada (1918): 75-79. These protests were mostly ignored and the few collections that were partially retrieved pertained to foreign Jesuits and were only recovered after diplomatic interventions.

6o Theodore Dru Alison Cockerell, "The exiled Naturalists of Portugal," Science 34, no. 882 (1911): 714-15. When referring to the expulsion of the Jesuits the prominent naturalist stated that: "a document has recently been circulated, bearing the name of twelve Portuguese naturalists [...] who have been exiled from their country by the new government, 'on the pretext that they are Jesuits.' [...] These men were professors in the colleges of S. Fiel and Campolide, in Lisbon, and were known for their work in different branches of biology, and especially for the journal Brotéria, which they published. [...] In the course 

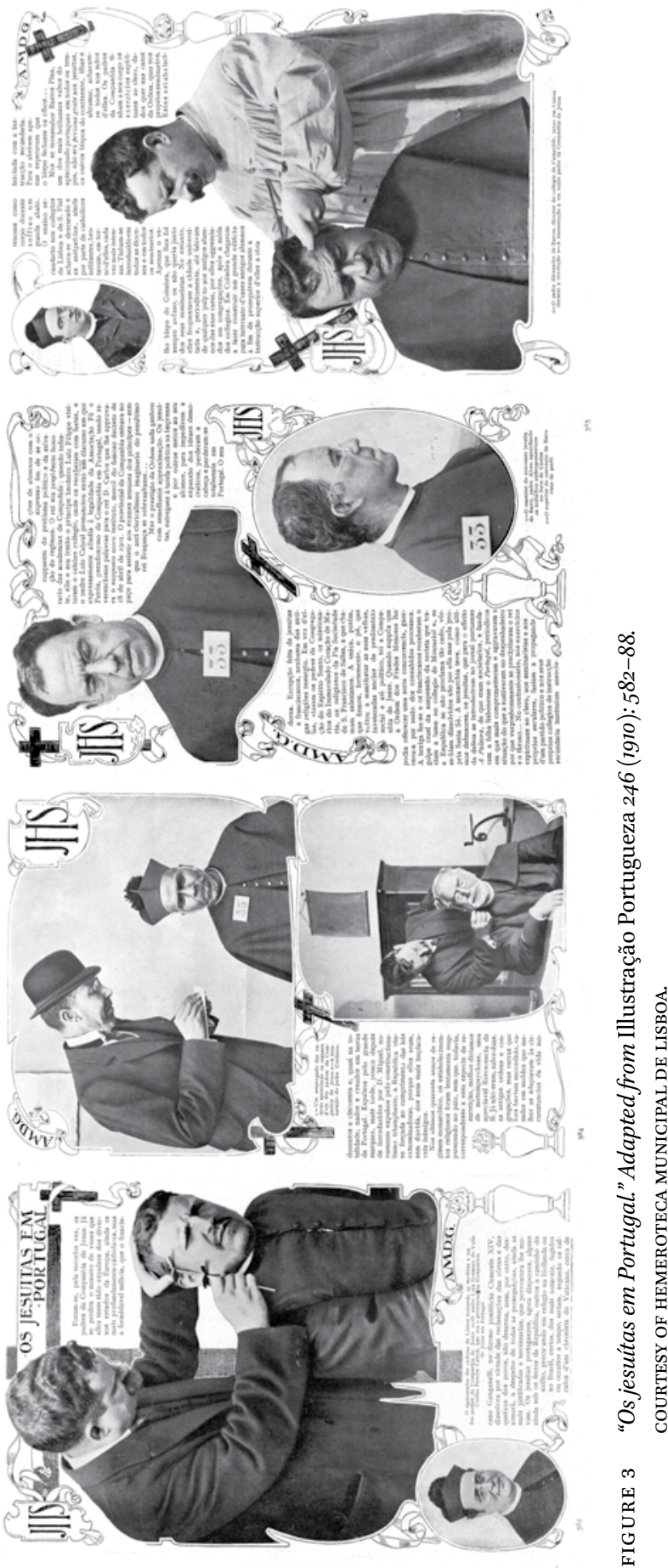
In the aftermath of the decree that banned the Society of Jesus and apprehended their assets, Afonso Costa imprisoned more than 130 Jesuits. As science and progress had always been at issue when discussing the Society of Jesus, the captors decided to make a public display of their modernity and their intellectual superiority. Republican physicians proudly allowed for photos to be taken while the most modern scientific methods were used to ascertain the workings of the mind of the religious fanatics. These photos are today the most vivid testimonies of the farcical absurdity that was the 1910 expulsion of the Society: the "reactionary and obscurantist" clerics under the humiliating examination included men who had done scientific research of international relevance and had, to the best of their abilities, tried to establish in Portugal the teaching of modern science; the "modern and enlightened" doctors usedand believed in - phrenology, one of the most ridiculous and absurd beliefs ever to have plagued the course of science (see Figure 3).

of the years, they had established an excellent library of works on natural history, a laboratory for microscopic work, and had accumulated large collections, especially of orthoptera, lepidoptera, gall-insects, and botanical specimens. The government ordered the arrest of these professors, and confiscated all their scientific possessions." Cockerell was particularly concerned with the collections because they "were accumulated for special ends, and it will not be possible for others to make the best use of them. In many cases the specimens are not labeled, and in others they are marked with numbers, abbreviations, etc., intelligible only to their original owners." 